Al-Amwal: Jurnal Ekonomi dan Perbankan Syariah
ISSN: 2303-1573 e-ISSN: 2527-3876
Homepage: https://www.syekhnurjati.ac.id/jurnal/index.php/amwal
email: jurnalalamwal@syekhnurjati.ac.id

\title{
CUSTOMER'S DECISIONS TO SAVE IN SHARIA BANKING AMONG JAKARTA MILLENNIAL
}

\author{
Adelia Irmawanti \\ Fakultas Ekonomidan Bisnis Islam IAIN Salatiga \\ Rosana Eri Puspita \\ Fakultas Ekonomidan Bisnis Islam IAIN Salatiga \\ e-mail: rosana.eri.p@iainsalatiga.ac.id
}

\begin{abstract}
This study aims to analyze what factors influence a customer's decision to save at a sharia bank, especially in the DKI Jakarta. The variables of knowledge, religiosity, and promotion. The intention-to-save is the mediating variable. This study uses a quantitative approach with primary data collected through a questionnaire with a purposive sampling technique. The number of samples used in the study was 400 respondents who were customers of all Islamic banks in Jakarta. Data analysis used regression test with the SPSS 20 application. The results showed that knowledge, religiosity, and promotion had a positive and significant effect on the intention-to-save. The intention has a positive and significant effect on customer decisions. Knowledge, religiosity and promotion have a positive and significant effect on saving decisions. And the last, intention-to-save, can mediate knowledge, religiosity, and promotion of saving decisions. Islamic banks must continue to improve each of the customer's determinants to improve Islamic banks' existence.
\end{abstract}

Keywords: knowledge, religiosity, promotion, intentionto save, customer decisions.

\begin{abstract}
Abstrak
Penelitian ini bertujuan untuk menganalisis faktorapa saja yang mempengaruhi keputusan nasabah untuk menabung di bank syariah khususnya di wilayah DKI Jakarta dengan variabel pengetahuan, religiusitas dan promosi dan minat menabung menjadi variabel mediasi. Penelitian ini menggunakan pendekatan kuantitatif dengan data primer yang dikumpulkan melalui kuesione rdengan teknik purposive sampling. Jumlah sampel yang digunakan dalam penelitian sebanyak 400 responden yang merupakan nasabah seluruh bank syariah di Jakarta. Analisis data menggunakan uji regresi dengan aplikasi SPSS 20. Hasil penelitian menunjukan pengetahuan, religiusitas dan promosi
\end{abstract}


berpengaruh positif dan signifikan terhadap minat menabung. Minat berpengaruh positif dan signifikan terhadap keputusan nasabah. Pengetahuan, religiusitas dan promosi berpengaruh positif dan signifikan terhadap keputusan menabung. Minat menabung dapat memediasi pengetahuan, religiusitas dan promosi terhadap keputusan menabung. Bank syariah harus terus melakukan peningkatan dari setiap factor penentu keputusan nasabah tersebut untuk meningkatkan eksistensi bank syariah.

\section{Kata kunci: pengetahuan, religiusitas, promosi, niatmenabung, keputusan nasabah.}

\section{INTRODUCTION}

The development of the banking world has experienced rapid growth and has dominated the economy in Indonesia. The bank has the main task of collecting funds from parties with excess funds to be distributed to parties who need funds within a certain period(Marimin, Romdhoni, \& Fitria, 2015). Banking services also have a function to support national economic development, making the banking industry compete to be the best and maintain its existence. This improvement is carried out by the conventional banking industry in Indonesia and carried out by Islamic banking.

Islamic banks operate according to Islamic principles and are known by the public as banks without usury (Mujaddid \& Nugroho, 2019). Islamic banks are expected to improve the welfare of the people in Indonesia (Suparyanto, 2018). When viewed from its inception until now, Indonesia's Islamic banking industry has experienced a significant increase (Wahyulkarima, 2018). It can be seen based on data taken in August 2020, the number of main branch or sub-branch networks of Islamic banks in Indonesia is increasing every year. The number of main branch offices is 827 , sub-branch offices are 1,415, and cash offices are 554. Assets owned by Islamic banks also continue to grow until August 2020. The total assets of Islamic banks are 536,829.

The establishment of a sharia financial institution aims to develop a sharia economy in every transaction. The next question is how the community responds to the presence of sharia banks and whether they will decide to implement the sharia concept in their lives. If you look at this modern era, many people have started to switch to implementing a closer life to their God. Because society's pattern has begun to shift, the Sharia industry has a great opportunity to market its products.

Based on previous research, several factorscan influence customer decisions to save at Islamic banks. The essential factor that must be done to develop Islamic banking products among the public is knowledge (Wahyulkarima, 2018). Knowledge is all information that a consumer has about products or services and other things related to these products or services (Wardana, 2016). Religiosity, which is a religious act in a person related to the banking world, namely avoiding usury, is considered capable of influencing the decision to become a customer. This is supported by previous research conducted by (Zuhirsyan \& Nurlinda, 2018). A previous study states that promotional factors greatly influence making customer decisions to save at Islamic banks (Hasanuddin, SS, \& Nofrianto, 2019). The intention-to-save variable is also said to influence customer decision-making to save in Islamic banks. This is under previous research conducted by (Mahendrayasa, Kumadji, \& Abdillah, 2013). The intention to save that arises from consumers to save will be a driving force in determining customers' decisions to save in Islamic banks. 
The 2020 Islamic banking data snapshot issued by the OJK shows that Islamic banking's asset level and market share have increased. The largest distribution of assets was in DKI Jakarta at 54.27\% (OJK, 2020). However, the growth in assets and market share was still below that of conventional banking. The market share of the Islamic finance industry in Indonesia has indeed experienced growth from the previous year. However, it is still far behind when compared to conventional banks, which have a market share of $93.76 \%$, while Islamic banking is only $6.24 \%$ of the remainder. If you look at its potential, Islamic banks have great potential in Indonesia compared to conventional banks considering Indonesia has the largest Muslim majority globally. Conventional banks' superior market share indicates that most Muslim communities in Indonesia prefer to use conventional banks rather than Islamic banks.

One of the determining factors for customer intention to save in Islamic banking is knowledge. This opinion is reinforced by previous research which states that knowledge influences customers' intention to save in Islamic banking(Kristiyadi \& Hartiyah, 2016; Ramadhani, Susyanti, \& ABS, 2019). However, other research states that knowledge does not influence intention to save in the Islamic banking industry (Mujaddid \& Nugroho, 2019). Religiosity in previous research has also been stated to be one of the factors driving customer intention to save in Islamic banking(Fitria Nurma Sari \& Anwar, 2018; Khotimah, 2018). On the other hand, there is previous research which states that religiosity does not affect the intention to save in Islamic banking(Zakaria, Afifudin, \& Mawardi, 2020). Previous research also stated that promotion is also a factor for customers' intention to save in Islamic banking(Kristiyadi \& Hartiyah, 2016; Pradesyah, 2020). and other research states that promotion does not affect the intention to save in Islamic banks(Aisya \& Riyadi, 2020).

In determining customer decisions to save in Islamic banking, knowledge is one of the influencing factors(Megawati, 2015; Putribustami \& Paramita, 2018; Wahyulkarima, 2018). However, other research states that knowledge does not affect a customer's decision to save in Islamic banking(Rahmawati \& Hidayati, 2019). Then the previous research suggested that religiosity influences in determining the decision to save in Islamic banks(Bawono \& Oktaviani, 2016; Maisur, Arifin, \& M.Shabri, 2015; Zuhirsyan \& Nurlinda, 2018). But other research states that religiosity does not influence customers' decisions to save in Islamic banking(Pakkawaru, 2018). Promotion is also one of the determining factors for customer decisions in saving in Islamic banking(Gautama Siregar, 2018; Hasanuddin et al., 2019; Tajudin \& Mulazid, 2017). On the other hand, previous research has stated that promotion does not affect customers' decisions to save in Islamic banking(Fajar Fahrudin \& Yulianti, 2015). The intention to save that customers have in previous research is also said to be the most important factor in determining a customer's decision to save in Islamic banking(Fauzia, Pangestu, \& Bafadhal, 2019; Syahriyal, 2019).

The new thing in this study is Jakarta's millennial, who was used sample. Study about intention-to-use sharia banking Jakarta Millennial not be done yet. It is interesting because millennial has a unique characteristic which different with other generation.

\section{LITERATURE REVIEW Knowledge}

Knowledge is the output produced by the senses of an object. After the senses capture the object's information, the information will be conveyed, and knowledge is obtained (Putribustami \& Paramita, 2018). Knowledge is a change in individual 
behavior that comes from experience (Wardana, 2016). Each consumer has a different level of knowledge, where this knowledge will later be used to process the information obtained and then make decisions. When someone has more knowledge of something, the consumer will be better at making a decision.

Knowledge indicators are divided into four (Sumarwan, 2017). First, characteristic knowledge. Consumers have different abilities in mentioning an object's characteristics because consumers have different knowledge about an object. Second, product knowledge. Product knowledge contains a collection of information about the product, knowledge about product characteristics, brands, attributes, etc. Third, purchasing knowledge. Purchase knowledge can be in the form of knowledge about the object, the object's location, and the placement of a product in that object. Fourth, usage knowledge means products will provide maximum benefits and satisfaction if customers use the product correctly.

\section{Religiosity}

Religiosity is the act of someone related to the wider community in developing creative devotion to God. A religiosity is a form of complete integration between religious knowledge, feelings, and religious actions within a person(Zuhirsyan\& Nurlinda, 2018). A religiosity is also a form of belief in believing in one's religion by practicing and obeying all the rules contained therein and doing things related to worship happily without coercion. Religiosity, according to Islam, is carrying out religious teachings as a whole.

The indicators of religiosity are divided into five(Putriani \& Shofawati, 2015). First, the dimension of belief. This dimension of belief demands that religious practices be carried out following religious values. Second, the dimensions of religious practice. Things that are included in this dimension include worship, obedience, and other things that a person does in performing rituals in his religion. Third, the experience dimension. This dimension contains feelings or experiences that have been experienced or felt. Fourth, the dimension of religious knowledge. This dimension refers to a person's knowledge and understanding of his religion. Fifth, the dimension of practice measures the extent to which a person's behavior is motivated by religious teachings, for example, in social life such as helping and cooperating.

\section{Promotion}

Promotion is an activity that communicates the benefits of a product and persuades target consumers to buy the product (Tajudin \& Mulazid, 2017). The promotion aims to increase sales of a product (Hasanuddin et al., 2019). In a marketing mix activity, promotion is an activity carried out at the end of the process. In this stage, each bank tries to introduce all products and services that are owned either directly or indirectly (Putra \& Mulazid, 2018). Advertising, sales promotions, and personal sales are forms of promotion carried out by companies in introducing the products and services offered (Aisya \& Riyadi, 2020).

Five indicators can be used as promotional indicators (Setyaningsih \& Mufida, 2013). First, sales promotion. The forms of this promotion include discounts, coupons, displays, sweepstakes, and events. Second, advertising. Advertising is a form of nonpersonal presentation and promotion paid for by sponsors to present ideas, goods, or services. Third, personal selling is sales made face-to-face, which are expected to be able to influence customers. Fourth, public relations. Public relations is an effort from a program design to improve, maintain, or company or the image of a product - fifth, direct sales. Direct selling includes direct relationships with target consumers whose 
aim is to get responses as quickly as possible and build continuous relationships with consumers.

\section{Intention-to-Save}

In the large Indonesian dictionary, intention to save is defined as the heart's tendency towards a desire (Khotimah, 2018). Intention to save can be a driving factor that causes a person to pay more attention to an object. Intention to save is also said to be the cause of people doing something. Intention to save is present when an individual is interested in something according to his needs or feels he wants to learn it(Aisya \& Riyadi, 2020).

Intention to save indicators that can be used in the intention to savea variable, namely. First, transactional intention to save, which is a person's tendency to buy products. Second, referential intention to save is a tendency to refer a product to others. Third, preferential intention to save, where this intention to save describes the behavior of someone who prefers the product and the preference can only be replaced if something happens with his preference and finally, exploratory intention-to-save. This intention-to-save describes individuals who are always looking for information about the product they will buy and looking for their positive side.

\section{Customer's Decision}

The decision is to determineconsumers' choice for two or more alternatives deemed capable of meeting their needs (Augustinah \& Dwijosusilo, 2018). Basic psychological processes play an important role in understanding how consumers make their purchasing decisions(Aisyah, Umiyati, \& Apriansyah, 2017). The decision is a problem-solving process consisting of identifying needs and wants, searching for information, assessing selection sources for purchase alternatives, purchasing decisions, and post-purchase behavior.

The process of making a purchase decision for a product or service is described in the form of a purchasing activity process with the following stages-first, identification of needs. The buying process begins with the introduction of needs where potential customers recognize a problem or need. Prospective buyers feel the difference between the actual situation and the desired state. Second, information search. Interested potential buyers will be looking for more information. If the urge is strong and a satisfying service product is near the potential customer, the prospective customer will likely buy it. If not, prospective customers will store these needs in their memory or search for information related to their needs. Third, alternative evaluation, consumers process information to evaluate various alternatives. Consumers evaluate various alternative products or services to be purchased depending on each individual and the specific buying situation. Fourth, the purchase decision. The purchase decision is when consumers will buy or not-two factors influence: buying tendency and purchasing decisions. The first factor is the attitude of other people, and the second factor is the factor of unexpected situations. Consumers may form purchasing tendencies based on the income, price, benefits of the product or service-fifth, post-purchase behavior. After a product or service purchase occurs, the consumer will then experience a level of satisfaction or dissatisfaction. Buyer satisfaction or dissatisfaction with the product will affect subsequent behavior. Satisfied consumers will show higher buying opportunities at the next opportunity.

\section{Hypothesis Development}

In the Theory of Planned Behavior (TPB), the perception of behavior control is 
determined by a person's beliefs about the competencies that will support or inhibit the behavior (Ajzen, 2005). This means that when an individual has more knowledge of something, the individual can control the next action to be taken. According to research conducted previously, there is a positive and significant relationship regarding the interest in saving money in Islamic banking which is based on science (Kristiyadi \& Hartiyah, 2016; Ramadhani et al., 2019). From this explanation, it can be concluded that the first hypothesis for this research

H1: There is also a significant positive effect of knowledge on saving among Jakarta millennials in Islamic banking.

Relativity is the main factor that influences customer switching intention (Suwarsi, 2017). Religiosity can be realized from many sides of life, one of which is the economic aspect. It is felt that muamalah activities following Islamic law can be found in Islamic banks. Previous research states that there is a significant influence of religiosity on the interest in saving vocational students in Islamic banking (Mujaddid \& Nugroho, 2019). The level of religiosity can also influence intention to deposit money in Islamic banking (Damayanti, 2013). Then from this description, the second hypothesis for this research is obtained

$\mathrm{H} 2$ : There is a positive and significant influence of religiosity on the intention to save Jakarta millennials in Islamic banking

Promotion is an activity that offers and provides descriptions of the products offered to consumers interested in these products (Aisya \& Riyadi, 2020). Previous research has said that promotion influences people's intention to save in making transactions at Islamic banks (Pradesyah, 2020). Promotions carried out properly by the company will generate interest from customers to save their money in Islamic banks. From this description, the third hypothesis for this research is obtained.

H3: There is also a significant positive effect of promotion on saving Jakarta millennials in Islamic banking.

In the Theory of Planned Behavior (TPB), intention to save is a factor influencing action or behavior (Ajzen, 2005). There must first be an intention to save in DKI Jakarta people, which will later encourage their decision to save at an Islamic bank. Previous research results state that the intention to save factor influences the decision to save in Islamic banking in Banda Aceh (Syahriyal, 2019). Based on this description, the fourth hypothesis for this research is obtained.

H4: There is also a significant positive effect of intention to save in millennial Jakarta customers' decisions to save in Islamic banking.

Knowledge is a change in individual behavior that comes from experience(Kotler \& Keller, 2016). Each individual has a different level of knowledge to translate the information they get and make decisions. There is a positive and significant influence on customer decisions in choosing Islamic banks(Putribustami \& Paramita, 2018; Wahyulkarima, 2018). Based on the description, the fifth hypothesis for this research is obtained. 
H5: There is a positive and significant influence of knowledge on millennial Jakarta customers' decisions to save in Islamic banking.

The level of one's faith will determine an individual's economic behavior(Maisur et al., 2015). This behavior will then form a tendency in economic behavior such as consumption, production, and saving. This indicates that the level of a person's faith will affect his decisions, including choosing an Islamic bank. Like previous research, religiosity has a significant effect on customers' savings decisions in Islamic banks (Maisur et al., 2015; Zuhirsyan \& Nurlinda, 2018). From this description, then the sixth hypothesis is created.

H6: There is a positive and significant influence of religiosity on Jakarta millennial customers' decisions to save in Islamic banking.

Promotion can be used as a tool to influence consumers to buy a (Putra \& Mulazid, 2018). A study said that promotional variables positively influenced customer decisions to use Islamic bank products(Hasanuddin et al., 2019). Agree with previous research, promotional factors also positively influence customer decisions to save at the North Sumatra branch of the Islamic bank(Gautama Siregar, 2018). From this description, the following seventh hypothesis.

H7: There is also a significant positive effect of promotingJakarta millennial customers' decisions to save in Islamic banking.

The knowledge that a person has can determine his behavior in something (Wardana, 2016). Their knowledge of Islamic banks can also influence intention to save in Islamic banks owned by Jakarta millennials. If the intention to save held by the community is high, the customer's decision to save will also be higher. In previous research, it was stated that the intention to save as a mediating variable could strengthen the relationship between knowledge and the decision to save at Islamic banks (Syahriyal, 2019). From this description, then the eighth hypothesis is created.

H8: There is also a significant positive effect of knowledge on Jakarta millennial customers' decisions to save in Islamic banking with be mediated intention to save.

A high level of faith will greatly affect the customer's decision to save in an Islamic bank. Likewise, the intention to save in Islamic banks is also influenced by one's religiosity. Individuals with a high level of faith will always do things following the law of their religion. In muamalah, the individual will choose to be on the path ordered by his religious teachings. This is what makes the level of religiosity influence an individual's decision to save in a sharia bank, especially when the individual already intends to save. Then the hypothesis for research based on this description is obtained, namely:

H9: There is a positive and significant influence of religiosity on Jakarta millennial customers' decisions to save in Islamic banking by being mediatedintention-tosave.

Promotion can be used as a tool to influence consumers to buy a product (Putra \& Mulazid, 2018). The promotion or marketing that is carried out contains things that will 
later be able to attract the intention to save potential customers. When there is a sense of intention to save, usually consumers will quickly decide on purchase activity. From this description, the tenth hypothesis for this research is obtained.

H10: There is a positive and significant effect of promotingmillennial Jakarta customers' decision to save in Islamic banking with be mediated by the intention to save.

From the description of the above hypothesis, a research model is compiled as follows:

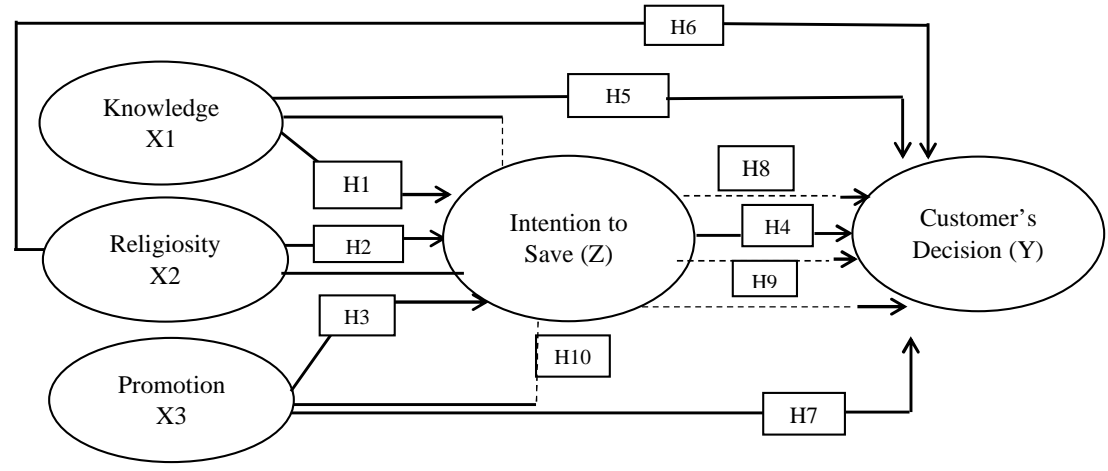

Figure 1. Research Model

\section{METHOD}

This research uses quantitative research. In this study, researchers researched Islamic bank customers with the millennial group's age criteria in the DKI Jakarta area. The time of the research was December-January 2020. This study's data source was primary data, where the data were obtained through online questionnaires. This study's measurement scale is the Likert scale 1-5 with the choice points of strongly disagree, disagree, neutral, agree, and strongly agree.

\section{Sampling Procedure}

The population in this study are millennials who are customers of Islamic banks in DKI Jakarta. Because the population in this study is known, the author uses the Slovin formula to take samples. The number of respondents in this study was 400 people who became customers of Islamic banks. The respondents' characteristics in this study were gender, age, occupation, education, and monthly expenses. The following table presents the classification data of respondents in this study.

Table 1. Respondents Data

\begin{tabular}{lr}
\hline Demographic respondent & Percentage \\
\hline Gender & \\
Male & 32.3 \\
Female & 67.8 \\
Age & \\
$17-22$ & 64.8 \\
$23-28$ & 33.0 \\
$29-34$ & 1.3 \\
$35-39$ & 1.0
\end{tabular}

\section{Profession}


College student

81.0

Government employees $\quad 1.0$

Private employees $\quad 9.3$

Entrepreneur $\quad 0.8$

Other

Education

Senior High School

Diploma (D1/D2/D3) 2.5

Bachelor (S1) 17.5

Postgraduate (S2) 0.5

Other

Monthly Expenses

$<\operatorname{Rp} 1.000 .000$

Rp 1.000.000 - Rp 2.000.000 40.3

Rp 2.000.001 - Rp 3.000.000 4.5

Rp 3.000.001 - Rp 4.000.000 2.8

$>\operatorname{Rp} 4.000 .000 \quad 2.8$

Source: Data processed in 2021

\section{Variable Operationalization}

Knowledge is the output produced by the senses of an object. After the purposes capture the object's information, the information will be conveyed, and knowledge is obtained (Putribustami \& Paramita, 2018). The indicators of knowledge used to measure this variable are characteristic knowledge, product knowledge, purchasing knowledge, usage knowledge.

A religiosity is a form of complete integration between religious knowledge, feelings, and religious actions within a person (Zuhirsyan \& Nurlinda, 2018). The indicators used to measure this variable are the dimension of belief (ideological), the dimension of religious practice (ritualistic), the dimension of experience (experiential), the dimension of religious knowledge (intellectual), and the dimension of experience (consequential).

Promotion is an activity that communicates the benefits of a product and persuades target consumers to buy the product (Tajudin \& Mulazid, 2017). The promotion aims to increase sales of a product (Hasanuddin et al., 2019). Promotion indicators used to measure this variable are sales promotion, advertising, personal selling, public relations, direct selling.

Intention to saveis defined as the inclination of the heart towards a desire (Khotimah, 2018). Intention to save is present when an individual is interested in something according to his needs or feels he wants to learn it (Aisya \& Riyadi, 2020). The indicators of an intention to save used to measure this variable are transactional intention to save, referential intention to save, preferential intention to save, and explorative intention to save.

The decision is to determineconsumers' choice for two or more alternatives 
deemed capable of meeting their needs(Augustinah \& Dwijosusilo, 2018). The decision indicators used to measure this variable are recognizing needs, seeking information, evaluating alternatives, purchasing decisions, and post-purchase behavior.

\section{Analysis Technique}

This research's analysis method is a validity test, reliability test, linear regression test, classical assumption test, and path analysis test operated with the SPSS program. SPSS is a statistical computer program application that quickly processes statistical data and produces the right output according to decision-making wishes.

Before entering the hypothesis test, this study has passed the research instrument's validity and reliability test. The validity test can be fulfilled if each indicator's calculated $r$-value is more than the $r$ table, namely, 0.098 with a significant $<0.05$. From the test results, it can be seen in Table 3 that no indication has a calculated r-value greater than the r-table, namely 0.098 , so it can be said to be valid.

The reliability test is measured by looking at the Cronbach Alpha value. The accuracy of the measurement scale can be seen from the size's consistency and stability (Amir et al., 2009). Reliability test in this study using the Cronbach alpha statistical test. If Cronbach alpha> 0.7, then a variable is declared reliable. In table 2 below, it can be seen that the reliability test results of all variable indicators have a Cronbach Alpha value above 0.7 , so it can be concluded that all measuring instruments used in this study are declared reliable.

Table 2. Validity and Reliability Test Results

\begin{tabular}{lc}
\hline Item & Loading \\
\hline Knowledge (CR = 0,831) & \\
Knowledge of what is an Islamic bank & 0,789 \\
Knowledge of products in Islamic banks & 0,913 \\
Knowledge of the location of Islamic banks & 0,906 \\
Knowledge of contracts in Islamic banks & 0,622 \\
Religiosity (CR = 0,738) & \\
Belief in God, Angels, Heaven, and Hell & 0,380 \\
Carry out religious orders and other muamalah practices & 0,737 \\
Carry out good behavior in everyday life & 0,738 \\
Carry out the teachings that exist in Islam & 0,735 \\
Belief in every action will get a reward from Allah SWT & 0,537 \\
Promotion (CR = 0,826) & \\
Interest in saving in Islamic banks because of advertising & 0,799 \\
Interest in saving in Islamic banks because of brochures & 0,834 \\
Interest in saving in Islamic banks because of gifts & 0,730 \\
Interest in saving in Islamic banks because the product & 0,772 \\
explanation is good & 0,713 \\
Interest in saving in Islamic banks due to charity activities & \\
Intention to save(CR = 0,750) &
\end{tabular}


The desire to save in an Islamic bank is because there are goals to be achieved

The desire to recommend a sharia bank to people around you $\quad 0,794$

The desire will not turn to banks other than Islamic banks $\quad 0,754$

The desire to find information related to Islamic banks $\quad 0,766$

Customer's Decision $(\mathbf{C R}=\mathbf{0 , 9 0 1 )}$

The decision to become a customer at an Islamic bank is because it can solve financial problems

0,829

The decision to save at an Islamic bank is based on the information obtained

0,804

The decision to save at an Islamic bank is because it can be an alternative financial management

0,895

The decision to save at an Islamic bank is because it can be an alternative financial management

0,879

The decision is satisfied with the products in Islamic banks

0,830

Source: Data processed in 2021

Table 2 shows the reliability instrument test's value by showing each variable's Cronbach alpha value in this research. From the table, it can be seen that the Cronbach alpha value for the knowledge variable is 0.831 , the religiosity variable is 0.738 , the promotion variable is 0.826 . The intention variable is 0.750 , and the decision variable is 0.901. All variables' Cronbach alpha value shows a number above 0.7 , meaning that all instruments in this research are reliable.

\section{RESULT AND DISCUSSION}

Result

The test used to prove the hypothesis in this research is to use regression analysis. This test is carried out to see the effect between the independent and dependent variables. The test tool used in research is the SPSS program.

Table 3. Determination and Adjusted R Square Test and T-Test Results and F-Test Results

\begin{tabular}{lccccccc}
\hline & \multicolumn{3}{c}{ Uji Determinasi R } & \multicolumn{2}{c}{ Uji T } & \multicolumn{2}{c}{ Uji F } \\
\cline { 2 - 8 } & $\mathrm{R}$ & $\mathrm{R}^{\mathbf{2}}$ & Adj. R & $\mathrm{T}$ & Sig. & F & Sig. \\
\hline KNon IN & 0,436 & 0,192 & 0,190 & 9,727 & 0,000 & 94,616 & 0,000 \\
REon IN & 0,370 & 0,137 & 0,135 & 7,955 & 0,000 & 63,276 & 0,000 \\
PRonIN & 0,641 & 0,411 & 0,410 & 16,677 & 0,000 & 278,135 & 0,000 \\
INonCD & 0,676 & 0,457 & 0,456 & 18,301 & 0,000 & 334,933 & 0,000 \\
KNonCD & 0,456 & 0,208 & 0,206 & 10,233 & 0,000 & 104,717 & 0,000 \\
REon CD & 0,239 & 0,057 & 0,055 & 4,911 & 0,000 & 24,121 & 0,000 \\
PRon CD & 0,583 & 0,340 & 0,338 & 14,318 & 0,000 & 205,012 & 0,000 \\
\hline
\end{tabular}

Source: Data processed in 2021

From the first hypothesis test, it can be seen that the R-value is 0.436 , R Square is 0.192, and Adjusted R Square is 0.190. From the R Square value, it can be seen that the role of knowledge in saving intention is $19.2 \%$. In other words, the remaining $80 \%$ is influenced by other factors than knowledge. Knowledge has a positive and significant 
effect on the intention to save. This can be seen from the regression test of 0.192 , with a $t$ value of 9.727 and a significance of 0.000 . This significance value is more than 0.05 , so Jakarta millennials' knowledge about Islamic banking can increase their intention to save. The F test was also carried out, which in this research resulted in the calculated $\mathrm{F}$ value of 94.616 with a significance value of 0.000 . These results can also imply that knowledge has a significant influence on saving Jakarta millennials in Islamic banking.

Furthermore, from the second hypothesis test, it can be seen that the R-value is 0.370, R Square is 0.137, and Adjusted R Square is 0.135. From the R Square value, it can be seen that the role of religiosity in saving interest is $13.7 \%$. In other words, the remaining $86.3 \%$ was influenced by factors outside of religiosity. Religiosity has a positive and significant effect on the intention to save. This can be seen from the regression test of 0.137 , with a $t$ value of 7.955 and a significance of 0.000 . The significance value is more than 0.05 so that the level of religiosity in millennial Jakarta can increase intention to save. The $\mathrm{F}$ test was also carried out, which resulted in the calculated $F$ value of 63.276 with a significance value of 0.000 . These results can also imply that religiosity has a significant influence on saving Jakarta millennials in Islamic banking.

The third hypothesis test shows that the R-value is 0.641 , R Square is 0.411 , and Adjusted R Square is 0.410 . From the value of $\mathrm{R}$ Square, it can be seen that the role of promotion in intention in saving is $41.1 \%$. In other words, the remaining $60 \%$ is influenced by other factors. The promotion has a positive and significant effect on intention in saving. This can be seen from the regression test of 0.411 , with a $t$ value of 16.677 and a significance of 0.000 . The significance value is more than 0.05 so that the promotion carried out by Islamic banking can increase intention to save. The $\mathrm{F}$ test was also carried out, which resulted in a calculated $F$ value of 278.135 with a significance value of 0.000 . These results can also imply that promotion significantly influences the intention-to-save Jakarta millennials in Islamic banking.

Furthermore, in the fourth hypothesis test, it can be seen that the R-value is 0.676, $\mathrm{R}$ Square is 0.457 , and Adjusted R Square is 0.456. From the R Square value, it can be seen that the role of intention to save decisions is $45.7 \%$. In other words, the remaining $54.3 \%$ is influenced by other factors. Intention to save has a positive and significant effect on saving decisions. This can be seen from the regression test of 0.457 , with a $t$ value of 18.301 and a significance of 0.000 . The significance value is more than 0.05 so that the existing intention to save in consumers can increase the decision to save. The $\mathrm{F}$ test was also carried out, which resulted in the calculated $F$ value of 334,933 with a significance value of 0,000 . These results can also imply that intentionsignificantly influences the decision-to-save Jakarta millennials in Islamic banking.

The fifth hypothesis test shows that the R-value is $0.456 \mathrm{R}$ Square 0.208 and Adjusted R Square 0.206. From the R Square value, it can be seen that the role of knowledge in decisions is $20.8 \%$. In other words, the remaining $79 \%$ is influenced by factors outside of knowledge. Knowledge has a positive and significant effect on saving decisions. This can be seen from the regression test of 0.208 , with a t value of 10.233 and a significance of 0.000 . The significance value is more than 0.05 so that the knowledge that Jakarta millennials have about Islamic banking can increase customer decisions. The $\mathrm{F}$ test was also carried out, which resulted in the calculated $\mathrm{F}$ value of 104.717 with a significance value of 0.000 . These results can also imply that knowledge significantly influencesJakarta millennial customers' decisions to save in Islamic banking. 
In the sixth hypothesis test, the R-value results are 0.239, R Square 0.057, and Adjusted R Square 0.055. From the R Square value, it can be seen that the role of religiosity in customer decisions is $5.7 \%$. In other words, the remaining $94 \%$ is influenced by factors outside of religiosity. Religiosity has a positive and significant effect on customer decisions. This can be seen from the regression test of 0.057 , with a $t$ value of 4.911 and a significance of 0.000 . The significance value is more than 0.05 so that the level of religiosity in Jakarta millennials can influence their decisions. The $F$ test was also carried out, which resulted in the calculated $F$ value of 24,121 with a significance value of 0,000 . These results can also imply that religiosity has a significant influence on Jakarta millennial customers' decisions to save in Islamic banking.

Based on the seventh hypothesis test, it can be seen that the R-value is $0.583, \mathrm{R}$ Square is 0.340, and Adjusted R Square is 0.338. From R Square's value, it can be seen that the role of promotion in customer decision interest is $34 \%$. In other words, the remaining $66 \%$ is influenced by other factors. The promotion has a positive and significant impact on customer decisions. This can be seen from the regression test of 0.340 , with a t value of 14.318 and a significance of 0.000 . The significance value is more than 0.05 so that the promotion carried out by Islamic banking can increase customer decisions. The F test was also carried out, which in this research resulted in a calculated $\mathrm{F}$ value of 205.012 with a significance value of 0.000 . These results can also imply that promotions significantly influenceJakarta millennial customers' decisions to save in Islamic banking.

Furthermore, the analysis model used to examine the mediating variables' role in this research is path analysis. This test is carried out to see how the mediating variable's role can become a bridge between the independent and dependent variables.

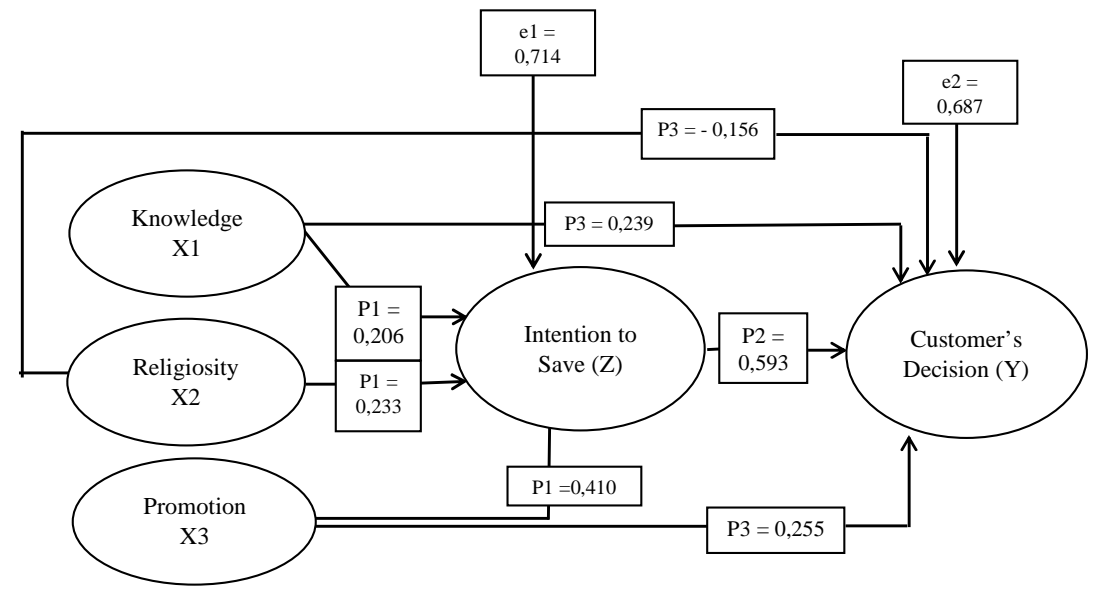

Figure 2. Model Path Analysis

The picture above shows the testing results through the path analysis carried out in this research. The test results are then retranslated for a single test, which will answer the hypothesis regarding the mediating variable's role in this research.

Table 4. Sobel Test Analysis

\begin{tabular}{lccc}
\hline KNtoCD viaIN & $\begin{array}{l}\text { RE to CD } \\
\text { via IN }\end{array}$ & $\begin{array}{c}\text { PR toCD } \\
\text { viaIN }\end{array}$ \\
\hline Direct Influence & 0,239 & $-0,156$ & 0,255 \\
Indirect Influence & 0,122 & 0,138 & 0,243
\end{tabular}




\begin{tabular}{lccc} 
Total Iinfluence & 0,361 & $-0,018$ & 0,498 \\
Influence of Sobel Test & 5,304 & 3,450 & 7,594 \\
Mediation & & \\
\hline
\end{tabular}

Source: Data processed in 2021

Based on the results of testing the eighth hypothesis, it can be seen that the direct effect of the knowledge variable on the decision is 0.239 . Furthermore, the indirect effect in this research is 0.122 , with a total effect of 0.361 . The mediating effect of intention calculated using the Sobel test obtained a value of 5.304. These results illustrate that indirectly knowledge impacts customers' decisions to save in Islamic banks according to the $t$ value, which is more than the $t$ table, namely 5.304> 1.649 and a significance of $5 \%$. The conclusion is that the mediation coefficient of 0.122 is significant, and there is a mediation effect. This means that research shows that their intention to savecan become a bridge for knowledge for customer decisions.

Furthermore, from the results of the ninth hypothesis testing, it can be seen that the direct effect of the religiosity variable on the decision is -0.156 . Furthermore, the indirect effect that occurs in this research is 0.138 with a total effect of -0.018 . The mediating effect of intention calculated using the Sobel test obtained a value of 3,450. These results illustrate that indirectly religiosity impacts customers' decisions to save in Islamic banks according to the $\mathrm{t}$ value, which is more than the $\mathrm{t}$ table, namely 3,450> 1.649 and a significance of $5 \%$. The conclusion is that the mediation coefficient of 0.138 is significant, and there is a mediation effect. This means that in research, it is proven that the intention they have can become a bridge for religiosity for customer decisions

And the last of the tenth hypothesis test shows that the direct effect caused by the promotion variable on decisions is 0.255 , then the indirect effect is 0.243 , and the total effect is 0.498 . For the effect of mediation through the Sobel test, the value was 7.594. These results imply that promotion indirectly affects customers' decisions to save at Islamic banks according to the $t$ value, which is more than the t-table, namely 7.594> 1.649 and a significance of $5 \%$. It can be concluded that the mediation coefficient of 0.243 is significant, and there is a mediating effect. This means that in this research, it is proven that the interests they have can be a bridge for promotion in customer decisions.

\section{DISCUSSION}

There is a positive and significant influence of knowledge variable on the intention-to-save in Islamic banks among DKI Jakarta millennials. It means that the first hypothesis in the research is accepted. The knowledge possessed by the DKI Jakarta millennial community about Islamic banking is considered good enough so that it directly proportional to increasing their intention to save at Islamic banks. This result is in line with previous research, which states that the knowledge possessed by a student will have a positive effect on his intention to save at an Islamic bank (Ramadhani et al., 2019). In line with previous research, customers who have more knowledge about religion will also increase their intention in moving and using sharia services (Kristiyadi \& Hartiyah, 2016).

In the results of further research, it is concluded that there is a positive and significant influence of the religiosity variable on the intention to save in Islamic banks in the DKI Jakarta millennial class so that $\mathrm{H} 2$ in the research is accepted. This result is in line with previous research that states that the religiosity factor can increase the intention to save in Islamic banks in vocational students. This was done as an effort to 
carry out the commands of Allah SWT and leave things that are prohibited by religion (Mujaddid \& Nugroho, 2019). The level of religiosity possessed by the DKI Jakarta millennial community is considered good enough so that it is directly proportional to increasing their interest in saving at Islamic banks.

The promotion factor in this research also has a positive and significant effect on Jakarta millennials' intention-to-save in Islamic banking. Promotion will provide all information on the products offered and then will influence customers to buy these products. This result is in line with previous research, which states that promotional factors can influence the intention to save in Islamic banks(Pradesyah, 2020). In line with previous research, the promotion has a positive and significant effect on the intention to save(Kristiyadi \& Hartiyah, 2016). The promotion carried out by the company is considered good, so that it is directly proportional to increasing intention to save at Islamic banks among DKI Jakarta millennials. It was then concluded that the increased promotion that was carried out would also increase customers' intention to save their money in Islamic banking.

Furthermore, the research concluded a positive and significant influence of the intention-to-save variable on customer decisions to save at Islamic banks among the DKI Jakarta millennial class. The fourth hypothesis in the research was accepted. This result is in line with previous research, which states that interest can influence a consumer's decision (Fauzia et al., 2019; Syahriyal, 2019). Companies' breakthrough to build interest in customers has had a big impact on increasing customer decisions to save in Islamic banking. Thepeople of Jakarta's intention to deposit their funds in Islamic financial institutions is considered good enough. It is directly proportional to increasing the millennial generation of DKI Jakarta's decisions to save their money in Islamic banks.

The positive influence is also significant from the knowledge variable on customer decisions to save at Islamic banks in the DKI Jakarta millennial class. The fifth hypothesis in the research is accepted. This result is in line with previous research, which states that knowledge is the dominant factor in determining customer decisions to choose Islamic banks (Wahyulkarima, 2018). The amount of knowledge that customers have about the Islamic banking industry is considered good enough. It is directly proportional to increasing the millennial generation of DKI Jakarta's decisions to save their money in Islamic banks. Previous research also said that knowledge plays an important role in saving Islamic banks in the Ponorogo community (Putribustami \& Paramita, 2018).

Then there is a positive and significant influence of the religiosity variable on customer decisions to save at Islamic banks in the DKI Jakarta millennial group to accept H6 in the research. This result is in line with previous research, which states that religiosity is an important factor in determining customer decisions to choose Islamic banks (Zuhirsyan \& Nurlinda, 2018). Also, previous research states that the level of religiosity will greatly influence the decision to save in Banda Aceh City (Maisur et al., 2015). The high level of faith in a customer is considered sufficient to make decisions by the millennial generation of DKI Jakarta to save their money in Islamic banks. Then the conclusion is drawn, the level of a customer's religiosity can be a factor in increasing the decision to save money in Islamic banking.

The same is the effect of the knowledge and religiosity factors. There is a positive and significant influence of the promotional variable on customer decisions to save at Islamic banks in the DKI Jakarta millennial class. The seventh hypothesis in the 
research is accepted. Promotions carried out by the Islamic banking industry are deemed good enough to make customers decide to save their money in the Islamic banking industry. This result is in line with previous research, which states that promotion is an important factor in determining customer decisions to choose Islamic banks(Hasanuddin et al., 2019). The good response obtained is an increase in the customer's decision to save their money in an Islamic bank, a form of promotion that is carried out correctly. The company's targets will be achieved when implemented with careful planning and maximum implementation.

Furthermore, the path test conducted states that there is an effect of mediation in the research. These results can explain, indirectly, the knowledge factor has a significant influence on the customer's decision to save in an Islamic bank through intention to save. It is in line with previous research that states that there is an influence on decisions and that the increasing number of decisions is due to their interests(Selviana, 2018). The research states that customers' knowledgeof the Islamic banking industry will automatically make customers interested in buying the product and then decide to use it. In this way, this research shows the effect of mediation that gives interest in knowledge, influencing Islamic banking customers' decision to save. When the millennial generation has sufficient knowledge about the Islamic banking industry, there must be an intention to savein using these products. The intention to save will turn into a buying decision to save money in Islamic banking.

The next path test carried out in the research indirectly affects the religiosity factor and significantly influences the customer's decision to save in an Islamic bank through interest. This also proves that interest can be a bridge for religiosity in determining customer decisions to save at Islamic banks to accept the ninth hypothesis in the research. This research is in line with previous research stating that religiosity influences the interest in saving in Islamic banks. This interest will turn that desire into a decision to use the product (Fauzia et al., 2019). The Muslim generation will have an interest in using products that are under what they embrace. After being sure of their intention to save, consumers then make behavioral changes, namely buying or using these services. Therefore intention to save is said to be a bridge in linking religiosity's influence on customer decisions.

The final test results conclude that indirectly the promotion factor has a significant influence on a customer's decision to save at an Islamic bank through intention to save. This is proof that interest can be a bridge for promotion in determining customer decisions to save at Islamic banks to accept the research's tenth hypothesis. When Islamic banking companies carry out promotional activities so that the millennial generation can accept, there must be an intention to save that arises when trying to use these products. When the intention to save is in his mind coupled with the lucrative promotions carried out by Islamic banks, the intention to save will turn into a purchase decision which in research is a decision to save at an Islamic bank.

\section{CONCLUSION}

From a series of data analysis results, hypothesis testing, and discussion, it can be concluded that all hypotheses in this research are accepted. First, the variable factor X (knowledge, religiosity, and promotion) has a positive and significant influence on saving $(Z)$ of saving Jakarta millennials in Islamic banking. Then, the next conclusion that can be drawn is that the variable $\mathrm{X}$ factor (knowledge, religiosity, promotion, and intention to save) has a positive and significant effect on Jakarta millennial customers' 
decisions ( $\mathrm{Y}$ ) to save in Islamic banking. This research also concludes that the mediating variable of intention to save (Z) influences variable $X$ (knowledge, promotion, and religiosity) on Jakarta's millennial customers' decisions to save at Islamic banks.

Based on the research and discussion results, the suggestions that can be put forward are as follows: for further research actors who take the same topic as this research, it is better to further expand the independent variables. Looking for other variables that will see other factors outside of this research related to things that can determine customer decisions to save in Islamic banking and add scientific references.

Further suggestions for Islamic banking institutions based on the research conducted, it is found that knowledge, religiosity, and promotion have a positive and significant influence on customer decisions. The suggestions given are based on research. The Islamic banking industry continues to educate the public about Islamic banking in Indonesia, both in operations and so on. Also, it is better to carry out promotional activities if Islamic banking should carry out more attractive activities and inspire people to want to use these savings products.

\section{REFERENCES}

Aisya, S., \& Riyadi, Y. A. (2020). Pengaruh Promosi Dan Kualitas Pelayanan Terhadap Minat Menabung Masyarakat Kelurahan Siranindi Di Bank Muamalat Indonesia Palu Sulawesi Tengah. Al-Kharaj: Journal of Islamic Economic and Business, 2(1), 16-33. https://doi.org/10.24256/kharaj.v2i1.1192

Aisyah, M., Umiyati, U., \& Apriansyah, R. (2017). Pengaruh Kualitas Pelayanan

Terhadap Keputusan Nasabah Dengan Religious Behaviour Sebagai Variabel Moderator (Studi Kasus Pada Produk Tabungan BNI Syariah). Liquidity, 6(2), 119-132. https://doi.org/10.32546/lq.v6i2.29

Ajzen, I. (2005). Attides, Personallity and Behavior. International Journal of Strategic Innovative Marketing, Vol. 3, p. 117.

Augustinah, F., \& Dwijosusilo, K. (2018). Pengaruh Label Halal Dan Religiusitas Terhadap Minat Beli Dan Keputusan Pembelian (Studi Pada Wardah Beauty House Surabaya). Jurnal Sketsa Bisnis, 5(1), 49-59.

Bawono, A., \& Oktaviani, M. F. R. (2016). Analisis Pemahaman, Produk, dan Tingkat Religiusitas terhadap Keputusan Mahasiswa IAIN Menjadi Nasabah Bank Syariah Cabang Salatiga. Muqtasid: Jurnal Ekonomi Dan Perbankan Syariah, 7(1), 29. https://doi.org/10.18326/muqtasid.v7i1.29-53

Damayanti, F. (2013). Pembelajaran Berbantuan Multimedia Berdasarkan Teori Beban Kognitif untuk Meningkatkan Kemampuan Menyelesaikan Masalah Program Linear Siswa X TKR 1 SMKN 1 Doko. Jurnal Pendidikan Sains, 1(2), 133-140.

Fajar Fahrudin, M., \& Yulianti, E. (2015). Pengaruh promosi, lokasi, dan kualitas layanan terhadap keputusan pembelian nasabah Bank Mandiri Surabaya. $\begin{array}{lllll}\text { Journal of Business \& Banking, } & \text { 5(1), }\end{array}$ https://doi.org/10.14414/jbb.v5i1.478

Fauzia, diah retno sufi, Pangestu, E., \& Bafadhal, A. S. (2019). Pengaruh religiusitas, sertifikasi halal, bahan produk terhadap minat beli dan 
keputusan pembelian. Jurnal Administrasi Bisnis (JAB), 66(1), 37-46.

Fitria Nurma Sari, F., \& Anwar, M. (2018). Pengaruh Tingkat Religiusitas Santri Pondok Pesantren Darussalam Kediri Terhadap Minat Menabung di Perbankan Syariah. Jurnal Ekonomi Islam, 1(1), 25-35.

Gautama Siregar, B. (2018). Pengaruh Produk Dan Promosi Terhadap Keputusan Menjadi Nasabah Tabungan Marhamah Pada Pt. Bank Sumut Cabang Syariah Padangsidimpuan. TAZKIR: Jurnal Penelitian Ilmu-Ilmu Sosial Dan Keislaman, 4(1), 1. https://doi.org/10.24952/tazkir.v4i1.1060

Hasanuddin, R., SS, A. S., \& Nofrianto. (2019). Pengaruh Produk, Pelayanan dan Promosi terhadap Keputusan Nasabah untuk Menabung di Bank Syariah. INNOVATIO: Journal for Religious Innovation Studies, 19(2), 191-206. https://doi.org/10.30631/innovatio.v19i2.90

Khotimah, N. (2018). pengaruh religiusitas, kepercayaan, citra perusahaan dan sistem bagi hasil terhadap minat nasabah menabung dan loyalitas di bank syariah mandiri (Studi Kasus Pada Nasabah Bank Syariah Mandiri Gresik). Jurnal Ilmu Ekonomi \& Manajemen, 05(01), 37-48.

Kotler, P., \& Keller, K. L. (2016). Marketing Management. Canada: Person Publishing.

Kristiyadi, \& Hartiyah, S. (2016). Pengaruh Kelompok Acuan, Religiusitas, Promosi dan Pengetahuan Tentang Lembaga Keuangan Syariah terhadap Minat Menabung di Koperasi Syariah (Studi Kasus pada BMT TAMZIS Wonosobo). Ekonomi Dan Teknik Informatika, 5(Hutabarat 2010), 44-63.

Mahendrayasa, A. C., Kumadji, S., \& Abdillah, Y. (2013). PENGARUH WORD OF MOUTH TERHADAP MINAT BELI SERTA DAMPAKNYA PADA KEPUTUSAN PEMBELIAN ( Survei pada Mahasiswa Pengguna Kartu Selular GSM “ IM3 ” Angkatan 2011 / 2012 dan 2012 / 2013 Fakultas Ilmu Administrasi Universitas Brawijaya Malang ). Jurnal Administrasi Bisnis (JAB), 12(1), 1-7.

Maisur, Arifin, M. arfan, \& M.Shabri. (2015). Pengaruh Prinsip Bagi Hasil, Tingkat Pendapatan, Religiusitas Dan Kualitas Pelayanan Terhadap Keputusan Menabung Nasabah Pada Bank Syariah di Banda Aceh. Jurnal Magister Akuntansi Pascasarjana, 4(2), 1-8.

Marimin, A., Romdhoni, A. H., \& Fitria, T. N. (2015). PERKEMBANGAN BANK SYARIAH DI INDONESIA. Jurnal Ilmiah Ekonomi Islam, 01(02), 75-87.

Megawati. (2015). Analisis Pengetahuan Konsumen Mengenai Perbankan Syariah dan Pengaruhnya Terhadap Keputusan Menjadi Nasabah Pada PT Bank Tabungan Negara Syariah Cabang Makassar. Jurnal Minds, 2(2), 103119.

Mujaddid, F., \& Nugroho, P. T. A. (2019). Pengaruh pengetahuan, reputasi, lingkungan dan religiusitas terhadap minat pelajar Sekolah Menengah Kejuruan prodi perbankan Syariah dalam menabung di bank Syariah. Jurnal Ekonomi Islam, 10(1), 14-37.

OJK, O. (2020). Snapshot Perbankan Syariah Indonesia 2020: Posisi September 
2020.

Pakkawaru, I. (2018). Pengaruh Tingkat Religiusitas, Kualitas Layanan Terhadap Keputusan Menabung dan Informasi Sebagai Variabel Moderating. Bilancia, 12(2), 365-387.

Pradesyah, R. (2020). Pengaruh Promosi Dan Pengetahuan Terhadap Minat Masyarakat Melakukan Transaksi Di Bank Syariah (Studi Kasus Di Desa Rahuning). Jurnal Ekonomi Islam, 1(2), 123-143. https://doi.org/10.30596/al-sharf.v

Putra, E. R. H., \& Mulazid, A. S. (2018). pengaruh lokasi, bagi hasil dan promosi terhadap proses keputusan nasabah menabung di PT. Panin Dubai Syariah Bank. JUrnal Studi Ekonomi Dan Bisnis Islam, 3(1), 17.

Putriani, Y. H., \& Shofawati, A. (2015). Pola Perilaku Konsumsi Islami Mahasiswa Muslim Fakultas Ekonomi dan Bisnis Universitas Airlangga Ditinjau Dari TIngkat Religiusitas. Jurnal Ekonomi Syariah Teori Dan Terapan, 2(7), 570. https://doi.org/10.20473/vol2iss20157pp570-582

Putribustami, C. A., \& Paramita, R. A. S. (2018). Pengaruh Pelayanan, Lokasi, Pengetahuan, Dan Sosial Terhadap Keputusan Menabung Di Ponorogo. Jurnal Ilmu Manajemen (JIM), 6(3), 157-172.

Rahmawati, E., \& Hidayati, N. (2019). Pengaruh Karakteristik Nasabah, Pengetahuan Nasabah , Kualitas Pelayanan Terhadap Keputusan Menggunakan Jasa Perbankan Syariah ( Studi Pada Bank Kalsel Syariah Banjarmasin ). 8(1).

Ramadhani, N. Ik., Susyanti, J., \& ABS, M. K. (2019). Analisis Pengaruh Tingkat Religiusitas, Pengetahuan dan Lingkungan Sosial Terhadap Minat Menabung Mahasiswa di Bank Syariah Kota Malang. E-Jurnal Riset Manajemen, 79-87.

Selviana, N. (2018). Pengaruh Pengetahuan Dan Brand Image Terhadap Keputusan Menabung Dengan Minat Sebagai Variabel Intervening ( Studi Kasus Pada Bprs Suriyah Kc Salatiga ) Skripsi. Salatiga: IAIN Salatiga. SKRIPSI, 1-104.

Setyaningsih, E. D., \& Mufida, E. (2013). KEPERCAYAAN TERHADAP LOYALITAS PENGGUNA INTERNET BANKING PADA BANK CIMB NIAGA. 30-36.

Sumarwan, U. (2017). PERILAKU KONSUMEN Teori dan Penerapannya dalam Pemasaran (kedua; R. Sikumbang, Ed.). Bogor: Ghalia Indonesia.

Suparyanto, D. (2018). Prospek Perbankan Syariah di Indonesia. AL-INSYIROH, 2(1), 184-195.

Suwarsi, A. A. (2017). IDENTIFIKASI POTENSI NASABAH BARU BANK SYARIAH DITINJAU DARI CUSTOMER SWITCHING INTENTION. Jurnal Ekonomi Dan Bisnis Islam, 3(2).

Syahriyal, S. (2019). Pengaruh Persepsi Nilai Dan Pengetahuan Masyarakat Terhadap Minat Menabung Serta Dampaknnya Kepada Keputusan Menabung Pada Perbankan Syariah Di Banda Aceh. Jurnal Perspektif Ekonomi Darussalam, $4(1)$ 139-156. 
https://doi.org/10.24815/jped.v4i1.10930

Tajudin, M. H., \& Mulazid, A. S. (2017). Pengaruh Promosi, Kepercayaan Dan Kesadaran Merek Terhadap Keputusan Nasabah Menggunakan Produk Tabungan Haji (Mabrur) Bank Syariah Mandiri Kcp. Sawangan Kota Depok. ISLAMICONOMIC: Jurnal Ekonomi Islam, 8(1), 19-46. https://doi.org/10.32678/ijei.v8i1.64

Wahyulkarima, A. (2018). Pengaruh Budaya, Psikologis, Pelayanan, Promosi, dan Pengetahuan tentang Produk Terhadap Keputusan Nasabah dalam Memilih Bank Syariah. Jurnal Hukum Ekonomi Syariah, 1(1), 51. https://doi.org/10.30595/jhes.v1i1.3712

Wardana, M. A. (2016). Pengaruh pertimbangan, pengetahuan, sikap nasabah terhadap keputusan nasabah memilih produk bank Syariah di kota Denpasar. Jurnal Perspektif Ekonomi Darussalam, 14(1), 1.

Zakaria, L. D., Afifudin, \& Mawardi, M. C. (2020). Pengaruh religiusitas, fasilitas layanan, literasi keuangan dan bagi hasil terhadap minat mahasiswa untuk menabung di bank syariah. Jurnal Ekonomi Dan Bisnis, 09(11), 2526.

Zuhirsyan, M., \& Nurlinda, N. (2018). Pengaruh Religiusitas dan Persepsi Nasabah terhadap Keputusan Memilih Bank Syariah. Al-Amwal: Jurnal Ekonomi Dan Perbankan Syari'ah, 10(1), 48. https://doi.org/10.24235/amwal.v10i1.2812 